\title{
Perancangan Sistem Informasi Sekolah Kejuruan dengan Menggunakan Metode Waterfall (Studi Kasus SMK PGRI 1 Kota Serang-Banten)
}

\author{
Irwanto \\ Universitas Sultan Ageng Tirtayasa \\ E-mail: irwanto.ir@untirta.ac.id
}

\begin{abstract}
Abstrak
Pengembangan sistem informasi ini bertujuan untuk menghasilkan suatu sistem layanan informasi di SMK PGRI 1 Kota Serang sebagai sistem dan sumber informasi yang layak. Teknologi informasi digunakan sebagai sarana, baik kegiatan non akademis maupun akademis. Pemanfaatan internet untuk penyampaian informasi belum di terapkan di SMK PGR1 Kota Serang. Sistem informasi sekolah berbasis website merupakan solusi dan objek dari penelitian ini.Penelitian yang digunakan adalah penelitian Research and Deveopment (R\&D) dengan model pengembangannya waterfall yang terdiri dari 4 (empat) tahap yaitu Analisis, Desain, Pengodean dan Pengujian. Model pengembangan menggunakan waterfall atau juga disebut (air terjun) ini sering juga disebut model sekuensial linier (sequential linear) atau disebut juga alur hidup klasik (classic life cycle). Teknik pengambilan data yang digunakan yaitu wawancara dengan wakil bidang kurikulum SMK PGRI 1 Kota Serang, observasi, uji coba ke 30 responden serta 2 orang ahli media. Hasil penelitian yang didapat adalah nilai skor rata-rata validasi ahli media yang didapatkan sebesar 72,5 dengan kategori sangat layak. Adapun hasil dari pengguna didapatkan skor nilai sebesar 71,96 dengan kategori sangat layak. Jadi dapat disimpulkan bahwa perancangan sistem informasi sekolah kejuruan dapat dikembangkan dengan menggunakan metode penelitian dan pengembangan, dengan model waterfall dengan tahapan-tahapan penelitian diantaranya yaitu analisis, desain, pemrograman dan pengujian. Proses pembuatan sistem informasi sekolah diantaranya membuat flowchart dan storyboard, menetapkan dan menyusun konten, merancang proses alur sistem informasi sekolah berdasarkan dengan susunan konten yang sudah dibuat dengan bantuan aplikasi sublime text editor.
\end{abstract}

Kata kunci: Perancangan, Sistem, Informasi, Pengembangan, Waterfall

\section{Vocational High School Information System Design Using the Waterfall Method (Case Study of SMK PGRI 1 Serang City-Banten)}

\begin{abstract}
The development of this information system aims to produce an information service system at SMK PGRI 1 Serang City as a system and a proper source of information. Information technology is used as a means, both non-academic and academic activities. The use of the internet for information delivery has not been implemented in SMK PGR1 Serang City. The website-based school information system is the solution and object of this research. The research used is Research and Development (R\&D) research with the waterfall development model, consisting of 4 (four) stages namely Analysis, Design, Coding and Testing. Development models using a waterfall or also called (waterfall) are often called linear sequential models (linear sequential) or also known as the classic life cycle. The data collection technique used was interviews with
\end{abstract}


representatives of the curriculum field of SMK PGRI 1 Serang City, observation, trials of 30 respondents and 2 media experts. The results obtained were the average score of media expert validation obtained was 72.5 with very worthy category. The results from the users obtained a value score of 71.96 in the very feasible category. So it can be concluded that the design of vocational school information systems can be developed using research and development methods, with the waterfall model with research stages including analysis, design, programming and testing. The process of making school information systems includes making flowcharts and storyboards, setting and compiling content, designing school information system flow processes based on the composition of content that has been made with the help of a sublime text editor application.

\section{Keywords: Design, Systems, Information, Development, Waterfall}

\section{PENDAHULUAN}

Sekolah Menengah Kejuruan (SMK) salah satu bagian dari institusi pendidikan yang memanfaatkan perkembangan teknologi informasi.Perkembangan teknologi informasi merambah ke SMK mampu memberi dampak baik yang dapat bermanfaat untuk meningkatkan mutu pendidikan di sekolah tersebut.Teknologi informasi digunakan sebagai sarana, baik kegiatan non akademis maupun akademis.Pemanfaatan teknologi informasi ini juga digunakan sebagai media promosi sekolah kepada para calon siswa yang hendak masuk ke sekolah tersebut.

Sistem informasi sekolah berbasis website ini diharapkan mampu mempermudah masyarakat Indonesia khususnya Kota Serang untuk mengetahui salah satu instansi pendidikan misalnya mengetahui guruguru yang ada disekolah, prestasi yang diraih oleh sekolah, lulusan yang bekerja di perusahaan, serta kegiatan-kegiatan sekolah yang sedang berlangsung. Untuk siswa-siswi sekolah dapat dimanfaatkan untuk mengetahui pengumumanpengumuman terkait sekolah, mengetahui alumni yang sudah bekerja di perusahaan, serta mampu melakukan pemantauan pembayaran sekolah secara online. Disisi lain sistem informasi berbasis website ini berpotensi meningkatkan pemerataan dalam mengakses suatu informasi sekolah dalam lingkup yang luas.

SMK PGRI 1 Kota Serang merupakan sekolah yang termasuk sekolah yang sangat baik karena akreditasi sekolah tersebut sudah "A" sehingga sudah semestinya media informasi yang digunakan oleh sekolah dapat berupa website yang diakses oleh internet karena dari penglihatan peneliti siswa-siswi SMK PGRI 1 Kota Serang banyak yang sudah memiliki handphone.Peneliti memanfaatkan handphone yang digunakan oleh siswasiswi SMK PGRI 1 Kota Serang selain sebagai penunjang belajar, dengan handphone juga dapat digunakan sebagai sarana untuk mendapatkan informasi tentang sekolah baik dalam bidang akademis maupun non akademis. Dari hasil wawancara dengan bidang kurikulum SMK PGRI 1 Kota Serang, beliau mengatakan bahwa dahulu pernah ada website tentang sekolah SMK PGRI 1 Kota Serang namun sekarang website itu sudah eror sehingga dengan ini beliau mengharapkan adanya sebuah sistem informasi yang mampu memberikan sebuah informasi terkait sekolah sehingga masyarakat luas khususnya Kota Serang mengetahui apa saja yanga ada di SMK PGRI 1 Kota Serang dari 
mulai profil sampai fasilitas-fasilitas yang diberikan oleh SMK PGRI 1 Kota Serang.Putra \& Sutjahjo (2017) menjelaskan pengertian sistem yaitu, kumpulan dari beberapa elemen yang saling berhubungan satu dengan yang lainnya sehingga dapat dikatakan sebagai sistem, hal ini sama dengan pernyataan dari Manurung (2019) bahwa, sesuatu dikatakan sistem terdiri dari kesatuan yang utuh dari beberapa bagian yang saling berhubungan dan saling berinteraksi sehingga mencapai suatu tujuan tertentu.

Adapun beberapa karakteristik atau sifat-sifat sistem. Rahman, Susetyo \& Primasari (2019) menjelaskan bahwa, memiliki komponen-komponen (components), batas sistem (boundary), lingkungan luar sistem (environments), penghubung (interface), masukan (input), keluaran (output), pengolah (proces) dan sasaran (objectives) atau tujuan (goal) merupakan karakteristik sistem.

Davis dalam (Putra \& Sutjahjo, 2017) memaparkan bahwa informasi adalah kumpulan dalam bentuk data yang sudah diolah menjadi sesuatu yang memiliki arti bagi penerimanya atau pembacanya dan memiliki manfaat untuk pengambilan keputusan di waktu yang tepat. Adapun pengertian informasi lebih singkatnya yang di jelaskan oleh Fauzi, Erniawati \& Setyawan (2019) bahwa informasi merupakan sebuah data yang sudah diproses atau diolah menjadi sebuah file dalam bentuk paragraf maupun gambar-gambar. Perbedaan sedikit antar pendapat Manurung (2019) dengan sebelumnya dari sudut pandang bentuk yang lebih menjurus ke fungsi informasi tersebut. Informasi dikatakan sebagai hasil dari pengolahan data kedalam bentuk yang lebih berguna lagi untuk penerimanya yang didalamnya menggambarkan suatu kejadian-kejadian nyata dan mampu digunakan untuk alat bantu pengambilan suatu keputusan. Sama halnya dengan Jogianto (Sihombing \& Khumaini, 2016) bahwa, data yang sudah diolah dan menjadi sebuah bentuk yang berarti bagi penerimanya.

Sistem informasi merupakan kegiatan pengolahan data yang dapat di awali dengan mengumpulkan informasi, memperosesnya, menganalisis informasi yang didapat, menyimpan informasi, selanjutnya menyebarkan informasi yang telah di saring dari proses sebelumnya untuk kemanjuan serta kepentingan suatu individu maupun organisasi (Wardani, 2013). Sistem informasi juga diartikan oleh Kristanto yaitu, suatu kesatuan dari beberapa perangkat yang didalamnya terdiri dari perangkat keras,perangkat lunak komputer dan perangkat manusia sehingga nantinya data yang diperoleh oleh perangkat-perangkat tersebut di olah menggunakan perangkat keras dan perangkat lunak (Hariyanto \& Prasetyo, 2019).Rahman, Sustyo, \& Primasari (2019) mendefinisikan sistem informasi bahwa, suatu sistem dalam suatu organisasi yang menyatukan kebutuhan pengolahan transaksi harian, mendukung operasi, bersifat manajerial dan kegiatan strategi dari suatu organisasi dan menyediakan pihak luar tertentu dengan laporan-laporan yang diperlukan.UML merupakan singkatan dari Unifed Modeling Language.

UML ini merupakan sebuah standarisasi bahasa pemodelan muncul pada perkembangan teknik pemrograman berorientasi objek untuk pembangunan perangkat lunak yang dibangun dengan menggunakan teknik pemrograman berorientasi objek (Hariyanto \& Prasetyo, 2019).Pemodelan dengan menggunakan Unified Modeling Language (UML) merupakan metode pemodelan berorientasi objek dan berbasis visual.UML merupakan sebuah metodologi yang berkolaborasi antara 
metoda-metoda booch, OMT (Object Modeling Technique) dan juga OOSE (Object Oriented Software Engineering) dan beberapa metode lainnya (Nugroho, 2009). Internet merupakan jaringan global yang terbentuk dari ratusan atau bahkan ribuan komputer termasuk didalamnya jaringan-jaringan lokal. Komputer-komputer ini yang saling terhubung ini menjadi satu kesatuan melalui saluran telepon. Hal ini dikatakan oleh Bustami \& Ahmad (Manurung, 2019). Macbride juga mengartikan internet sebagai jaringan komunikasi secara global yang terbuka dan menghubungkan ribuan jaringan komputer, melalui sambungan telepon umum maupun pribadi (pemerintah maupun swasta). Penjelasan yang disampaikan hampir sama dengan yang dikatakan oleh tokoh sebelumnya.Internet juga bisa dikatakan sebagai teknologi yang digunakan untuk saling bertukar antara satu sama lain berbagai macam informasi dengan siapapun dan dimanapun orang tersebut berada tanpa ada batasan ruang dan waktu. Semakin berkembangnya waktu kemajuan teknologikhususnya internet, disalah satu sisi memberi manfaat dan berbagai kemudahan-kemudahan yang di rasakan bagi manusia namun disisi lain internet juga mampu memberikan masalah baru (Hanapi, 2019).

Internet memiliki banyak manfaat dalam dunia penididikan salah satu manfaat yang dapat dan mampu dirasakan manusia dari internet adalah hasil penyelesaian tugas peserta didik dikarenakan ada nya pemanfaatan internet yang digunakan dengan baik namun dibarengi dengan faktor lain sehingga mampu menghasilkan hasil pekerjaan penyelesaian tugas yang memuaskan dan sesuai yang diharapkan (Anita \& Tasrif, 2019). Sebelum masyarakat mengenal nama PHP nama lain sebelum nama PHP merupakan FI
(Form Interface). PHP ini dibuat pertama kali oleh Rasmus Lerdoff. Awal dari bahasa PHP ini merupakan program CGI yang di fungsikan khusus untuk menerima input melalui form yang ditampilkan dalam bentuk browser web. Namun dengan menggunakan PHP sebagai bahasa untuk membuat website maka maintenance pun menjadi lebih mudah (Wardani, 2013).Bahasa program yang berbentuk skrip yang diletakkan di dalam serverweb disebut sebagai PHP. Situs website yang dinamis banyak yang memakai bahasa pemrograman PHP, namun dengan begitu tidak menutup kemungkinan juga digunakan sebagai pemakaian yang lain (Solikhin \& Riasti, 2013).

PHP merupakan sebuah bahasa untuk membuat halaman web yang interaktif yang menyatu dengan HTML yang di jalankan di sisi server. Server side scripting digunakan untuk pembangun halaman web yang berisikan sintaks dan perintah-perintah yang diberikan dan sepenuhnya dijalankan di server kemudian disertakan pada dokumen HTML. Bahasa ini sangat memungkinkan aplikasi web menyajikan halaman HTML dinamis dan interaktif dengan cepat dan mudah, yang dihasilkan server (Syam \& Arie, 2018). Wardani (2013) menjelaskan bahwa PHP ini berupakan merupakan bahasa yang sederhana selain itu bahasa ini juga disebut sebut sebagai bahasa interpreter dalam melakukan suatu perintah yang memiliki beberapa jesamaan atau kemiripan dengan bahasa $\mathrm{C}$ dan bahasa perl untuk membuat sebuah halamn website. Terakhir Hastanti, Purnama \& Wardati (2015) memberikan pendapatnya bahwa bahasa PHP ini merupakan bahasa pemrograman dalam berupa atau berbentuk skrip yang sederhana yang memiliki fungsi atau berguna untuk pemrosesan HTML Form di dalam sebuah halaman web sedangkan 
Nugroho (Suryadi \& Zulaikhah, 2019) hanya menyimpulkan bahwa PHP adalah bahasa program yang berbentuk skrip yang diletakan di dalam server web.Bahasa komputer yang standar American National Standard Institute (ANSI) yaitu SQL. Bahasa ini merupakan sebuah bahasa standar yang digunakan untuk mengakses dan melakukan manipulasi sistem database(Solikhin \& Riasti, 2013).

Beberapa perbedaan yang dikemukaan oleh Yakub, Junaedi menjelaskan bahwa MySQL merupakan salah satu jenis database server yang sampai sekarang masih banyak atau sering digunakan untuk membangun aplikasi website sehingga database ini menjadi cukup terkenal dibandingkan database lain, tidak sedikit orang-orang yang menggunakan database ini sebagai sumber dan sebagai pengelolaan data untuk sebuah website yang dibuatnya (Putra \& Sutjahjo, 2017). Bunafit Nugroho juga menyumbangkan pendapatnya mengenai pengertian MySQL ini, bahwa MySQL ini merupakan sebuah program penghasil database. MySQL sendiri tidak mungkin akan berjalan dengan sendirinya tanpa ada sebuah aplikasi pengguna (interface) yang mungkin saja berguna sebagai program aplikasi pengakses database yang dihasilkan. Program penghasil database ini mendapat dukungan oleh hampir semua atau banyak program aplikasi baik yang berupa open windows seperti Visual Basic, Delphi dan yang lainya (Wardani, 2013).MySQL ini menjadi populer di zaman sekarang ini karena diantaranya terdapat beberapa fitur pendukung yang sanagat membantu dalam mebuat sebuah website.Madcoms menjelaskan fitur-fitur yang mendukung didalam MySQL ini diantaranya adalahmultithreaded, multi-user, dan SQL databasemanagement system (DBMS). Database ini sengaja dibuat memang digunakan untuk keperluan sistem database yang cepat, handal, dan mudah digunakan sehigga sangat membantu sekali para pembuat website baik yang masih pemula maupun yang sudah terbiasa dalam membuat webiste (Hidayat \& Faisal, 2019).Faizal dan Irnawati juga menjelaskan bahwa MySQL ini sebagai perangkat lunak pada sebuah sistem manajemen berbasis data SQL (database management system) atau DBMS yang memiliki sifat multi thread dan multi user, dengan jumlahnya berkisar kurang lebih enam juta instalasi di seluruh dunia (Suryadi \& Zulaikhah, 2019).

Software-software yang di paparkan di atas harus sudah terpasang pada komputer untuk aplikasi XAMPP diunduh dari internet karena aplikasi tersebut bersifat open source. Pada saat implementasi atau pada saat digunakannya aplikasi maka apache web server harus diaktifkan terlebih dahulu agar aplikasi nya dapat berjalan sesuai dengan semestinya (Siregar \& Saiman, 2019).Wardana (Suryadi \& Zulaikhah, 2019) menjelaskan bahwa paketsoftware yang didalamnya terdapat beberapa software yang berkaitan untuk melakukan pengembangan diantaranya adalah Web Server, Apache, database MySQL, dan PHP interpreter hal ini di sebut sebagai XAMMP.

Dalam beberapa penjelasan diatas maka penulis dapat simpulkan bahwa XAMMP merupakan aplikasi yang didalamnya terdapat beberapa software yang berguna atau saling berkaitan sehingga dapat digunakan untuk melakukan sebuah pengembangan web. Dalam pembuatan sebuah website diperlukannya sebuah framework untuk mempermudah dalam pembuatan sebuah website tersebut.Salah satu framework yang dapat digunakan adalah codeigniter. Betha Sidik menjelaskan bahwa codeigniter ini merupakan 
framework PHP yang memiliki sifat open source dan memiliki metode MVC (Model, View, Controller) sehingga mampu memudahkan developer atau programmer dalam membangun atau membuat sebuah aplikasi berbasis web tanpa harus membuatnya dari awal (Destiningrum \& Adrian, 2017).Tujuan utama dari codeigniter ini adalah agar dapat memudahkan seseorang programmer dalam mambuat atau mengembangkan sebuah aplikasi dengan cepat tanpa harus dengan melakukan pemrograman lagi dari nol. Sehingga, programmer yang telah memiliki dasar pemrograman bahasa PHP, mampu bekerja lebih cepat sehingga dapat menghasilkan aplikasi sesuai dengan apa yang dibutuhkan (Pamungkas, 2015). Codeigniter ini merupakan framework yang mampu membuat sebuah sistem aplikasi web yang kompleks dengan menggunakan format PHP.

Dengan codeigniter ini mampu mempercepat dalam proses pembuatan sebuah web, karena semua kelas dan modul yang dibutuhkan dalam pembuatan sebuah web sudah ada, sehingga programmer hanya tinggal menggunakan fungsi dari kelas dan modulnya kembali pada aplikasi web yang hendak akan dibuat (Prabowo, 2015).Sistem informasi ini berisi konten yang dapat mempermudah siswa maupun siswi dalam mendapatkan informasiinformasi yang ada di lingkungan sekolah maupun di luar sekolah serta mempermudah melakukan pembayaran uang bulanan sekolah.Bagi siswa dan siswi SMK PGRI 1 Kota Serang dapat melakukan dimulai dari pendaftaran anggota, login sebagai anggota dan form pembayaran uang sekolah bulanan bagi yang belum menyelesaikan administrasi tagihan sekolahnya.Rangkaian sebuah kerangka pikir penulis dijelaskan pada Gambar 1 berikut ini.

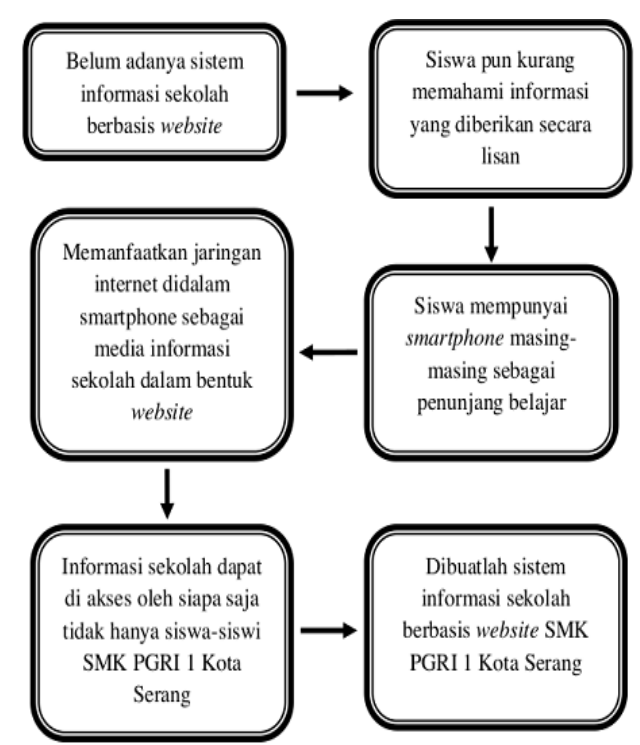

Gambar 1. Kerangka Pikir Penelitian

Tujuan pengembangan dari rancang bangun sistem informasi website ini diantaranya (a) mengetahui langkahlangkah rancang bangun sistem informasi sekolah berbasis website di SMK PGRI 1 Kota Serang, dan (b) mengetahui uji kelayakan rancang bangun sistem informasi sekolah berbasis website di SMK PGRI 1 Kota Serang.

\section{METODE}

Penelitian sistem informasi sekolah menggunakan penelitian $\mathrm{R} \& \mathrm{D}$ (Research and Development) dengan model waterfall. Model waterfall ini merupakan model pengembangan yang menyediakan pendekatan alur hidup perangkat lunak dengan cara sekuensial atau dikatakan secara terurut yang di awali dengan analisis, desain, pengodean, pengujian, serta tahap pendukung (Rosa \& Shalahuddin, 2018). Model pengembangan waterfall (air terjun) ini sering juga disebut model sekuensial linier (sequential linear) atau disebut juga alur hidup klasik (classic life cycle). Model waterfall ini adalah model yang paling tua dan sudah banyak digunakan untuk mengembangkan rekayasa perangkat lunak.Model 
waterfall ini merupakan pengembangan perangkat lunak yang sistematik dan sekuensial.Tahapan dari model ini diantaranya yaitu analisis, desain, pemrograman dan pengujian (Baihaqi, 2019).

Prosedur pengembangan layanan informasi sekolah SMK PGRI 1 Kota Serang ini menggunakan metode pengembangan R\&D dan dengan model pengembangan waterfall.Berikut ini merupakan tahapan-tahapan yang digunakan model waterfall, dilihat pada Gambar 2.

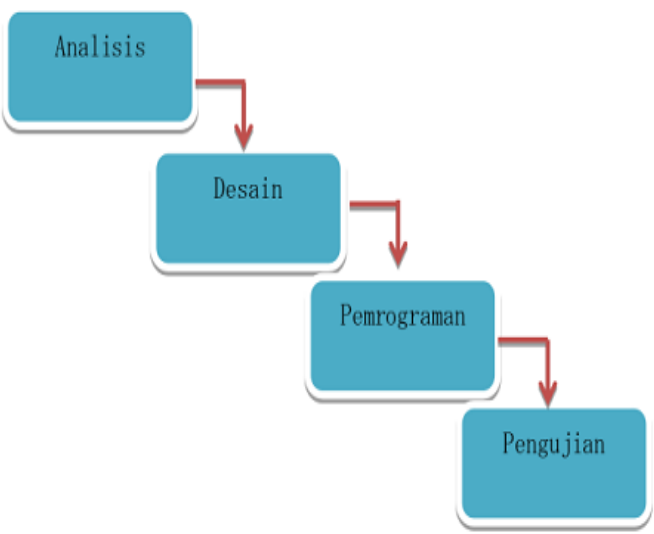

Gambar 2. Prosedur Pengembangan Waterfall

(Sumber: Rosa \& Shalahuddin, 2018)

Subjek dalam uji coba ini diantaranya adalah guru, bidang keuangan, bidang tata usaha, masyarakat dan siswa SMK PGRI 1 Kota Serang.Uji coba yang diteliti adalah dari kualitas dan kelayakan sistem informasi tersebut, objek dari penelitiannya adalah kelayakan sistem informasi.Teknik pengumpulan data yang digunakan oleh peneliti menggunakan tiga teknik dalam mengumpulkan data yaitu observasi, wawancara dan studi pustaka.Tujuan dari teknik pengumpulan data ini adalah untuk mendapatkan data-data yang dibutuhkan lalu kemudian di analisis. Berikut penjelasan dari tiga teknik pengumpulan data diantaranya: observasi, dilakukannya sebuah observasi berguna untuk memperoleh informasi mengenai kelakukan manusia sepertihalnya dalam bentuk kenyataan. Selain itu observasi berfungsi sebagai eksplorasi, dari ini kita mampu memperoleh gambaran yang lebih jelas mengenai suatu masalah dan mungkin mampu mendapatkan petunjuk-petunjuk untuk cara memecahkan masalah tersebut (Nasution, 2016).

Pengumpulan data menggunakan metode (1) Observasi ini memiliki kelebihan dan kekurangan, kelebihannya diantaranya: memiliki keandalan yang tinggi, melihat langsung apa yang dikerjakan, mencatat perilaku yang sulit diungkapkan, menggambarkan lingkungan fisik dengan detail. Kekurangannya diantaranya: orang yang diamati merasa terganggu, perilaku yang ingin di observasi tidak muncul, peneliti terlalu baik dalam melakukan penilaian, orientasi peneliti dan adanya batasan tempat dan waktu (Herdiansyah, 2013). Dalam penelitian ini melakukan observasi dengan mengamati pemberian informasi di SMK PGRI 1 Kota Serang dan juga mengamati permbayaran uang sekolah bulanan yang dilakukan oleh orang tua siswa yang terlambat dalam waktu pembayarannya.

(2)Wawancara merupakan suatu bentuk komunikasi dengan verbal atau seperti percakapan yang memiliki tujuan untuk memperoleh sebuah informasi. Cara melakukan pengumpulan data ini bisa melalui telepon dan juga dengan berhadapan langsung dengan lawan bicaranya. Manfaat dari wawancara ini kita mampu mendapatkan data dengan cara memasuki alam pikiran orang lain, sehingga kita mampu mendapatkan gambaran dari suatu hal yang pernah dialami orang lain (Nasution, 2016). Penelitian ini melakukan sebuah tanya jawab langsung kepada pihak-pihak yang bersangkutan dengan objek yang akan diteliti. Hasil wawancara yang didapat setidaknya mampu diharapkan untuk 
menambah kelengkapan data yang diperoleh dari hasil pengamatan yang dilakukan peneliti. (3) Studi pustaka, merupakan sebuah teknik pengumpulan data untuk memperoleh data yang bersumber dari literatur. Jenis-jenis literatur yang digunakan bukan hanya berupa buku-buku melainkan juga diperoleh dari sumber-sumber bacaan lain yang mampu menunjang proses penelitian.Manurung (2019) menjelaskan bahwa instrumen penelitian merupakan semua alat yang digunakan untuk mengumpulkan, memeriksa, mengolah, menganalisa dan menyajikan data-data secara sistematis serta objektif dengan tujuan memecahkan suatu persoalan atau menguji suatu hipotesis. Ada dua macam instrumen dalam pengumpulan data diantaranya: instrumen ahli media dan instumen pengguna.

Teknik analisis data dalam penelitian ini adalah menggunakan teknik analisis deskriptif.Teknik analisis deskriptif digunakan dengan menggunakan statistik deskriptif. Statistik analisis deskriptif ini merupakan statistik yang berfungsi sebagai mengenalisa suatu data yang sudah dikumpulkan dengan caramendeskripsikan data yang telah terkumpul tanpa membuat sebuah kesimpulan yang sbersifat umum.Data yang sudah dikumpul nantinya akan dianalisis dan diinterpretasikan sehingga nantinya mampu menjadi sebuah informasi. Proses analisis diawali dari pengolahan data - data yang sudah diperoleh menjadi data yang lebih sehingga harus dikomplekkan menjadi dua komplek data diantaranya, data berupa pernyataan dan angka. Tahap pertama dalam menganalisis data adalah dengan menggunakan deskriptif, memaparkan mengenai produk hasil rancangan sistem informasi setelah diimplementasikan dalam bentuk produk jadi dan menguji tingkat kelayakan dari produk tersebut.Setelah itu, tahap selanjutnya menggunakan deskriptif yang dikalkulasikan dengan angka yaitu, pemaparan mengenai kelayakan produk untuk diimplementasikan sekolah SMK PGRI 1 Kota Serang.Data yang dihasilkan dari proses pengembangan produk merupakan sebuah data yang sifatnya deskriptif. Dalam pengambilan data proses pengembangan produk ini diperoleh dari para ahli media dan para pengguna, bidang kurikulum, bidang keuangan dan IT serta siswa-siswi di SMK PGRI 1 Kota Serang, yang berupa koreksi dan masukan. Setelah itu koreksi dan masukan menjadi sebuah acuan dalam melakukan revisi produk untuk nantinya akan diimplementasikan di sekolah.

Data penilaian kelayakan produk oleh para ahli merupakan suatu data penilaian kelayakan produk sistem informasi sekolah berbasis web oleh para ahli media ini, diperoleh dari hasil isian angket yang sudah di isi oleh dua orang ahli media. Data yang sudah didapat, selanjutnya dianalisis dengan mengikuti langkah-langkah sebagai berikut:

1. Mengubah data penilaian berupa deskriptif menjadi angka dengan suatu ketentuan yang dapat dilihat pada Tabel 1 berikut:

Tabel 1. Ketentuan Pemberian Skor

\begin{tabular}{lc}
\hline \multicolumn{1}{c}{ Kategori } & Skor \\
\hline SS (Sangat Setuju) & 4 \\
S (Setuju) & 3 \\
TS (Tidak Setuju) & 2 \\
STS (Sangat Tidak setuju) & 1 \\
\hline
\end{tabular}

Sumber: (Sugiyono, 2014)

2. Menghitung rata-rata skor tiap indikator, hasil dari penskoran respon angket dapat dianalisis dengan cara menghitung rata-rata jawaban berdasarkan skoring setiap jawaban dari responden yang akan dihitung menggunakan rumus. Menghitung 
rata-rata skor tiap indikator dapat menggunakan rumus sebagai berikut:

Keterangan:

$$
\bar{x}=\frac{\sum_{i-1}^{n} x_{i}}{n}
$$

$$
\begin{array}{rlr}
\bar{x} & : \quad \text { Skor rata-rata hasil } \\
& \text { angketyang didapat. } \\
\sum_{i-1}^{n} x_{i}: & \text { Total skor masing-masing } \\
& \text { aspek } \\
n \quad & \begin{array}{l}
\text { Jumlah setiap aspek } \\
\text { evaluasiproduk barang } \\
\text { penilaian }
\end{array}
\end{array}
$$

Setelah data sudah diperoleh maka data diolah atau diproses untuk mengetahui seberapa besar tingkat kelayakan dari media pembelajaran berbasis web yang dikembangkan. Mengolah data hasil jumlah rerata skor tiap aspek dengan menggunakan kategori pengukuran sekala likert dengan ketentuan kriteria sebagai berikut.

Tabel 2. Konversi Data Berupa Angka ke Deskriptif

\begin{tabular}{ccl}
\hline $\mathbf{N}$ & \multicolumn{1}{c}{ Skor Siswa } & \multicolumn{1}{c}{$\begin{array}{c}\text { Kategori } \\
\text { Kelayakan }\end{array}$} \\
\hline 1. & $x \geq \bar{x}+1 . S B x$ & Sangat Layak \\
2. & $\bar{x} \geq S B x>\mathrm{x} \geq \bar{x}$ & Layak \\
3. & $\bar{x}>\mathrm{x} \geq \bar{x}-1 . S B x$ & Tidak Layak \\
4. & $\mathrm{x}<\bar{x}-1 . \mathrm{SBx}$ & Sangat Tidak Layak
\end{tabular}

Sumber: (Zohrani \& Aniah, 2017)

Keterangan:

$\mathrm{x}=$ Skor yang dicapai

$\bar{x} \quad=$ Rata-rata skor keseluruhan

$S B X=$ Simpangan baku skor keseluruhan

$\bar{x} \quad=(1 / 2)$ (skor maksimal ideal + skor minimal ideal)

$S B x=(1 / 6)$ (skor maksimal ideal - skor minimal ideal)

Skor Max ideal $=\Sigma$ Butir kriteria $\mathrm{x}$ skor tertinggi
Skor Min ideal $=\Sigma$ Butir kriteria $\mathrm{x}$ skor terendah.

\section{HASIL DAN PEMBAHAAN}

Penelitian yang digunakan dalam pengembangan produk ini menggunakan model waterfall yang terdiri dari 4 tahap diantaranya analisis, desain, pemrograman, dan pengujian. Produk yang dikembangkan pada penelitian ini berupa sistem informasi sekolah berbasis website.

Tahap Analisis Analisis yang dilakukan pada tahap awal ini yaitu mencari sebuah permasalahan, permasalahan didapat setelah melakukan wawancara kepada bidang kurikulum SMK PGRI 1 Kota Serang serta dengan melakukan observasi di SMK PGRI 1 Kota Serang. Tujuan dari analisis awal ini adalah untuk mengidentifikasi masalah-masalah yang ada di lapangan khusus nya di SMK PGRI 1 Kota Serang.Berdasarkan hasil wawancara dengan bidang kurikulum SMK PGRI 1 Kota Serang bahwa sekolah membutuhkan sebuah sistem informasi yang mampu dengan mudah diakses, cepat dan mengurangi penggunaan kertas namun juga mampu memberikan informasi tentang sekolah dengan luas tidak hanya di sekitar Kota Serang saja.Sebuah sistem informasi yang mampu menarik minat masyarakat untuk mempercayakan sekolah untuk mendidik anaknya.

Tahap Desain Tahap ini merupakan tahap dimana kebutuhan perangkat lunak yang sudah diperoleh diterjemah kedalam bentuk konsep perangkat lunak (software) yang nantinya akan dibuat. Pada user administrasi ini dibuat melalui database, dengan password dan username nya sudah diatur oleh programer. Jika terjadi kesalahan dalam penginputan username dan password maka akan muncul sebuah pengingat dalam tampilan login dan akan ada 
himbauan untuk melakukan percobaan kembali untuk memasukan password dan username. Beda halnya jika penginputan username dan password benar, maka akan menuju ke halaman utama dari administrator. Pada halaman ini memiliki beberapa menu diantaranya dashboard, data master, transaksi, laporan, menu utama, modul berita, modul vidio, modul iklan, modul web, modul interaksi, modul users, modul sekolah, edit profil dan logout.

Tahap Pemrograman (Coding), Pembuatan website dapat terjadi dengan adanya suatu penulisan kode atau program dengan bahasa tertentu sesuai dengan kemampuan dari pemrogramer.Bahasa program yang digunakan oleh pembuatan website kali ini adalah PHP dan Javascript.Awal mula pembuatan sistem informasi sekolah berbasis website ini menggunakan software sublime dengan bahasa pemrograman PHP. Dalam proses perancangan aplikasi menggunakan bahasa pemrograman Javascript .

Tahap pengujian merupakan tahapan yang selanjutnya dilakukan ketika sistem atau website sudah diterima atau disetujui oleh ahli media termasuk program, menu ataupun konten-konten yang sudah dibuat di tahap perancangan dan sudah siap untuk di operasikan. Tujuan dari tahap perancangan adalah ada pada tahap ini yaitu tahap dimana rancangan yang sudah dibuat pada tahap perancangan akan diujikan. Website informasi sekolah ini sudah siap untuk dipergunakan dalam penyampaian informasi dengan dua user diantaranya User administrasi dan User siswa yang hendak berinteraksi pada website ini.

Setelah dilakukan pengujian maka didapatkan hasil dari ujicoba pengguna yaitu terdiri tiga aspek.Tiga aspek yang dinilai yaitu aspek akurasi, aspek komunikasi visual, dan aspek penginputan data. Pengguna dari website sistem informasi sekolah ini yaitu staff TU, staff keuangan dan administrasi, masyarakat, siswa, dan guru. Berdasarkan hasil dari data yang telah didapat pada aspek akurasi mendapat total presentase sebesar $91,04 \%$, aspek komunikasi visual mendapat total presentase sebesar $87,87 \%$ dan terakhir aspek penginputan data mendapat total presentase sebesar $89,58 \%$. Berdasarkan data tersebut dapat dikatakan website sistem informasi sekolah ini sangat layak digunakan karena masing-masing aspek sudah melebihi total presentase $75 \%$.

\section{Data Hasil Uji Validasi Ahli Media}

Validasi ahli media merupakan sebuah validasi yang di berikan oleh dua ahli yang memiliki kompeten dalam bidangnya, pada penelitian kali ini dua ahli media yang menjadi validator adalah dosen pendidikan vokasional teknik elektro yaitu Mustofa Abi Hamid, S.Pd.,M.Pd.T dan wakil kepala bidang kurikulum SMK PGRI 1 Kota Serang yaitu Hendra Firmansyah. Tahap validasi media ini dilakukan sebelum melakukan pengujian kepada pengguna website. Penilaian pada angket validasi ahli media yang diberikan oleh dua orang ahli media dapat dilihat dalam bentuk diagram batang seperti Gambar 3 .

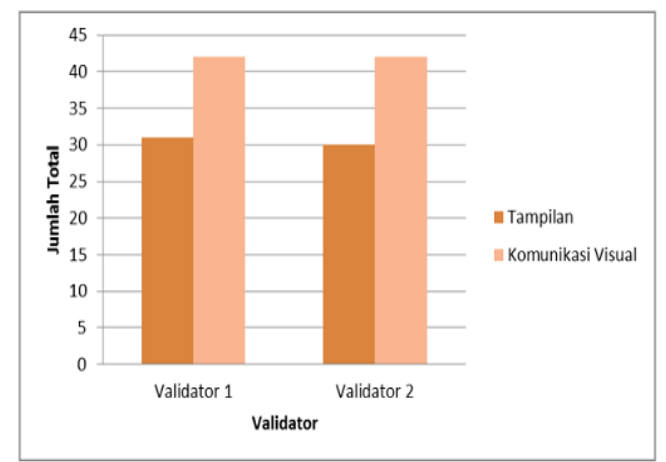

Gambar 3. Diagram Batang Validasi Ahli Media

Berdasarkan hasil dari diagram batang diatas maka dapat diketahui bahwa aspek tampilan pada validator 1 
ditunjukan sebesar 31 dan aspek tampilan pada validator 2 ditunjukan sebesar 30. Setelah itu pada diagram batang diatas juga dapat diketahui bahwa aspek komunikasi visual pada validator 1 dan validator 2 menunjukan jumlah total yang sama yaitu 42. Selanjutnya maka kita bisa menghitung kelayakan media dari tabel hasil penelitian yang sudah di dapatkan pada berkas yang terlampir. Berikut perhitungan kelayakan media berdasarkan hasil penelitian yang telah didapat:

a. Rata-rata skor hasil yang dicapai

$$
\begin{aligned}
& \bar{x}=\frac{\sum_{i-1}^{n} x_{i}}{n} \\
& \bar{x}=(73+72) / 2 \\
& \bar{x}=145 / 2 \\
& \bar{x}=72,5
\end{aligned}
$$

b. Skor Maksimal dan Skor Minimal

1) Skor Maksimal Ideal $=\sum$ Butir Instrumen x Skor Tertinggi

$$
=20 \times 4
$$$$
=80
$$

2) Skor Minimal Ideal $=\sum$ Butir Instrumen x Skor Terendah

$$
\begin{aligned}
& =20 \times 1 \\
& =20
\end{aligned}
$$

c. Rata-rata Keseluruhan

$\bar{x}=1 / 2($ Skor Max. Ideal + Skor Min. Ideal)

$$
\begin{aligned}
& \bar{x}=1 / 2(80+20) \\
& \bar{x}=1 / 2(100) \\
& \bar{x}=50
\end{aligned}
$$

d. Simpangan Baku

$$
\begin{aligned}
& \mathrm{SB}_{\mathrm{x}}=1 / 6 \text { (Skor Max. Ideal - Skor } \\
& \text { Min. Ideal) } \\
& \mathrm{SB}_{\mathrm{x}}=1 / 6(80-20) \\
& \mathrm{SB}_{\mathrm{x}}=1 / 6(60) \\
& \mathrm{SB}_{\mathrm{x}}=10
\end{aligned}
$$

Perhitungan yag telah diuraikan diatas maka dapat disimpulkan hasil rerata skor sebesar 72,5 dengan skor maksimal sebesar 80 dan skor minimal sebesar 20 . Simpangan baku dari instrumen sebesar
10. Setelah mendapatkan hasil masingmasing skor maka langkah selanjutnya, menkonversi hasil yang telah didapatkan ke dalam tabel konversi.Berikut ini perhitungan rentang skor pada tabel konversi skor validasi media.

a. Rentang skor sangat layak

$\mathrm{X} \geq \overline{\mathrm{X}}+1 . \mathrm{SB}_{\mathrm{x}}$

$X \geq 50+1(10)$

$X \geq 50+10$

$X \geq 60$

b. Rentang skor layak

$\overline{\mathrm{X}}+\mathrm{SB}_{\mathrm{x}}>\mathrm{X} \geq \overline{\mathrm{X}}$

$50+10>X \geq 50$

$60>X \geq 50$

c. Rentang skor tidak layak

$\overline{\mathrm{X}}>\mathrm{X} \geq \overline{\mathrm{X}}-1 . \mathrm{SB}_{\mathrm{X}}$

$50>X \geq 50-1(10)$

$50>X \geq 50-10$

$50>X \geq 40$

d. Rentang skor sangat tidak layak

$\mathrm{X}<\overline{\mathrm{X}}-1 . \mathrm{SB}_{\mathrm{x}}$

$X<50-1(10)$

$X<50-10$

$\mathrm{X}<40$

Setelah didapatkan hasil perhitungan untuk rentang skor, maka selanjutnya rentang skor yang sudah di hitung atau diolah dimasukan ke dalam tabel konversi.Berikut ini tabel konversi untuk menentukan kategori kelayakan.

Tabel 3. Konversi Kategori Kelayakan Ahli Media

\begin{tabular}{lccl}
\hline No. & Skor & $\begin{array}{c}\text { Rentang } \\
\text { Skor }\end{array}$ & $\begin{array}{c}\text { Kategori } \\
\text { Kelayakan }\end{array}$ \\
\hline 1. & $x \geq \bar{x}+$ & $\mathrm{x} \geq 60$ & Sangat Layak \\
& $1 . S B x$ & & \\
2. & $\bar{x}+S B x$ & $60>\mathrm{x}$ & Layak \\
& $>\mathrm{x} \geq \bar{x}$ & $\geq 50$ & \\
3. & $\bar{x}>\mathrm{x}$ & $50>\mathrm{x} \geq$ & Tidak Layak \\
& $\geq \bar{x}-$ & 40 & \\
& $1 . S B x$ & & \\
4. & $\mathrm{x}<\bar{x}-$ & $\mathrm{x}<40$ & Sangat Tidak \\
& $1 . \mathrm{SBx}$ & & Layak \\
\hline
\end{tabular}

Berdasarkan hasil perhitungan yang telah didapat dan berdasarkan tabel 
konversi kelayakan diatas bahwa sistem informasi sekolah SMK PGRI 1 Kota Serang berbasis website yang telah divalidasi oleh dosen pendidikan vokasional teknik elektro dan wakil kepala bidang kurikulum SMK PGRI 1 Kota Serang dapat dikatakan "sangat layak" karena berada dalam rentang skor $\mathrm{x} \geq 60$ dimana $\mathrm{x}$ didapat dari hasil ratarata angket validasi yaitu 72,5 . Sehingga degan demikian sistem informasi sekolah berbasis website ini dapat dikatakan siap dan sangat layak digunakan untuk SMK PGRI 1 Kota Serang.

\section{Data Hasil Uji Pengguna}

Tahap ini merupakan tahap perhitungan data dari hasil penilaian yang telah dilakukan oleh pengguna.Pada tahap ini terbagi dari beberapa aspek diantaranya aspek akurasi, komunikasi visual dan penginputan data. Berikut ini diagram dan perhitungan berdasarkan data yang sudah terlampir dapat dilihat pada Gambar 4.

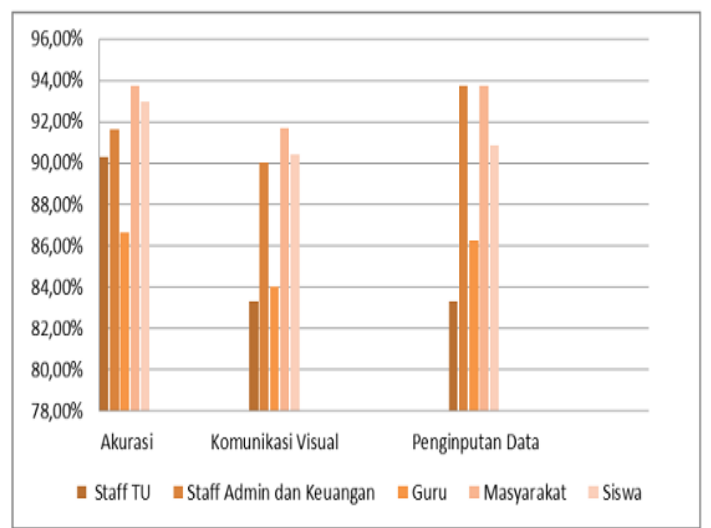

Gambar 4. Diagram Batang Hasil Uji Pengguna

Dilihat dari diagram batang diatas maka dapat kita ketahui bahwa aspek akurasi pada staff TU menunjukan presentase sebesar 90,27\%, staff admin dan keuangan menunjukan presentase sebesar 91,60\%, Guru menunjukan presentase sebesar $86,66 \%$, masyarakat menunjukan presentase sebesar $93,75 \%$ dan yang terakhir siswa menunjukan presentase sebesar 92,94\%. Pada aspek komunikasi visual staff TU menunjukan presentase sebesar $83,33 \%$, staff admin dan keuangan menunjukan presentase sebesar 90\%, Guru menunjukan presentase sebesar $84 \%$, masyarakat menunjukan presentase sebesar 91,66\%, dan yang terakhir yaitu siswa menunjukan presentase sebesar 90,38\% . Selanjutnya aspek yang terakhir yaitu aspek penginputan data pada staff TU menunjukan presentase sebesar $83,33 \%$, staff admin dan keuangan menunjukan presentase sebesar 93,75\%, Guru menunjukan presentase sebesar $86,25 \%$, masyarakat menunjukan presentase sebesar $93,75 \%$, dan yang terakhir yaitu siswa menunjukan presentase sebesar $90,86 \%$.

Setelah mendapatkan presentase dari masing-masing aspek, selanjutnya kita dapat menghitung uji media yang di nilai oleh pengguna berdasarkan tabel hasil penelitian yang sudah di dapatkan pada berkas yang terlampir. Berikut perhitungan uji media yang dinilai oleh pengguna berdasarkan hasil penelitian yang telah didapat:

a. Rata-rata skor hasil dicapai

$$
\begin{aligned}
& \bar{x}=\frac{\sum_{i-1}^{n} x_{i}}{n} \\
& \bar{x}=2159 / 30 \\
& \bar{x}=71,96
\end{aligned}
$$

b. Skor maksimal dan skor minimal

Skor Maksimal Ideal $=\sum$ Butir Instrumen x Skor Tertinggi

$$
\begin{aligned}
& =20 \times 4 \\
& =80
\end{aligned}
$$

Skor Minimal Ideal $=\sum$ Butir Instrumen $\mathrm{x}$ Skor Terendah

$$
\begin{aligned}
& =20 \times 1 \\
& =20
\end{aligned}
$$

c. Rata-rata keseluruhan

$\bar{x}=1 / 2($ Skor Max. Ideal + Skor Min.

Ideal)

$\bar{x}=1 / 2(80+20)$

$\bar{x}=1 / 2(100)$ 


$$
\bar{x}=50
$$

d. Simpangan Baku

$$
\begin{aligned}
& \mathrm{SB}_{\mathrm{x}}=1 / 6 \text { (Skor Max. Ideal }- \text { Skor } \\
& \text { Min. Ideal) } \\
& \mathrm{SB}_{\mathrm{x}}=1 / 6(80-20) \\
& \mathrm{SB}_{\mathrm{x}}=1 / 6(60) \\
& \mathrm{SB}_{\mathrm{x}}=10
\end{aligned}
$$

Pada perhitungan dan diagram yang sudah dilakukan maka didapatkan besar rata-rata hasil angket pengguna yang didapat sebesar 71,96 dengan skor maksimal dan skor minimal ideal sebesar 80 dan 20. Berdasarkan hasil dari skor maksimal dan minimal ideal yang telah didapat maka adapun hasil simpangan baku yang didapat sebesar 10. Setelah mendapat masing-masing skor maka di konversikan dalam tabel konversi.Berikut perhitungan rentang skor tabel konversi.

a. Rentang skor sangat layak

$$
\begin{aligned}
& X \geq \bar{X}+1 . S B_{x} \\
& X \geq 50+1(10) \\
& X \geq 50+10 \\
& X \geq 60
\end{aligned}
$$

b. Rentang skor layak

$$
\begin{aligned}
& \bar{X}+\mathrm{SB}_{\mathrm{x}}>\mathrm{X} \geq \overline{\mathrm{X}} \\
& 50>10>\mathrm{X} \geq 50 \\
& 60>\mathrm{X} \geq 50
\end{aligned}
$$

c. Rentang skor tidak layak

$$
\begin{aligned}
& \bar{X}>X \geq \bar{X}-1 . S B_{x} \\
& 50>X \geq 50-1(10) \\
& 50>X \geq 50-10 \\
& 50 \quad X \geq 40
\end{aligned}
$$

d. Rentang skor sangat tidak layak

$$
\begin{aligned}
& \mathrm{X}<\overline{\mathrm{X}}-1 . \mathrm{SB}_{\mathrm{X}} \\
& \mathrm{X}<50-1(10) \\
& \mathrm{X}<50-10 \\
& \mathrm{X}<40
\end{aligned}
$$

Setelah mendapatkan hasil perhitungan rentang skor, maka selanjutnya rentang skor yang sudah di hitung dimasukan ke dalam tabel konversi.Dibawah ini tabel konversi untuk menentukan kategori kelayakan.
Tabel 4. Konversi Kategori Kelayakan Pengguna

\begin{tabular}{cccl}
\hline No. & Skor & $\begin{array}{c}\text { Rentang } \\
\text { Skor }\end{array}$ & $\begin{array}{c}\text { Kategori } \\
\text { Kelayakan }\end{array}$ \\
\hline 1. & $x \geq \bar{x}+$ & $\mathrm{x} \geq 60$ & Sangat Layak \\
& $1 . S B x$ & & \\
2. & $\bar{x}+S B x$ & $60>\mathrm{x}$ & Layak \\
& $>\mathrm{x} \geq$ & $\geq 50$ & \\
& $\bar{x}$ & & \\
3. & $\bar{x}>\mathrm{x}$ & $50>\mathrm{x} \geq$ & Tidak Layak \\
& $\geq \bar{x}-$ & 40 & \\
& $1 . S B x$ & & \\
4. & $\mathrm{x}<\bar{x}-$ & $\mathrm{x}<40$ & Sangat Tidak \\
& $1 . \mathrm{SBx}$ & & Layak \\
\hline
\end{tabular}

Kesimpulan yang bisa didapat berdasarkan tabel diatas bahwa website sistem informasi sekolah SMK PGRI 1 Kota Serang yang telah diujicoba oleh guru dan staff, siswa serta masyarakat maka dapat dikatakan "sangat layak" karena berada dalam rentang skor $\mathrm{x} \geq 60$ dimana $\mathrm{x}$ didapat dari hasil rata-rata angket ujicoba yaitu 71,96. Dengan begitu sistem informasi sekolah berbasis website ini dapat dikatakan siap dan sangat layak digunakan untuk SMK PGRI 1 Kota Serang.

Pada penelitian ini produk yang dapat dihasilkan adalah sebuah informasi sekolah SMK PGRI 1 Kota Serang berbasis website yang memiliki fungsi sebagai media penyampaian informasi dengan melalui bantuan jaringan internet serta memberikan pengecekan informasi pembayaran sekolah bagi siswa maupun siswi SMK PGRI 1 Kota Serang.

Website sistem informasi sekolah SMK PGRI 1 Kota Serang ini dilakukan pengembangan dengan melalui penilaian berupa validasi oleh dua validator ahli media dan satu validator instrumen. Berdasarkan hasil dari beberapa validator tersebut didapatkan saran serta masukan untuk dilakukannya perbaikan pada produk maupun instrumen penelitian sebelum nantinya akan di uji kepada 
pengguna. Ahli media satu memberikan saran untuk dilakukannya perbaikan produk agar produk yang sudah dibuat menjadi lebih baik lagi diantaranya yaitu: digantinya kata "Link Terkait" menjadi "Kerja sama Perusahaan".Selanjutnya setelah mendapatkan saran dari ahli media satu, peneliti mempertimbangkan terlebih dahulu oleh pembimbing.Akhirnya peneliti dan pembimbing pun bersepakat mengganti dan mengikuti saran yang diberikan oleh ahli media satu.Berikut ini tampilan sebelum direvisi dapat dilihat pada Gambar 5.

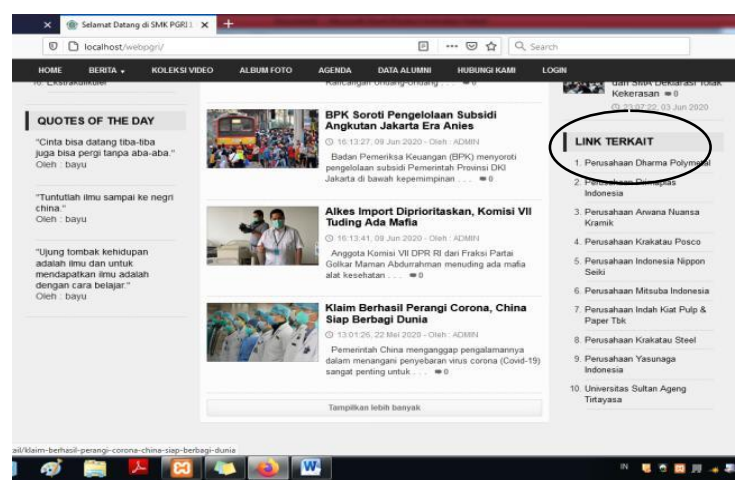

Gambar 5. Tampilan Link Sebelum Direvisi

Pada tampilan utama website sebelumnya di posisi sebelah kanan bawah terdapat judul "Link Terkait" dimana berisikan link-link perusahaan yang melakukan kerja sama oleh sekolah, kemudia ahli media satu pun memberi saran bahwa judul tersebut digantikan menjadi "Kerjasama Perusahaan" hal ini ditujukan agar masyarakat yang mencoba mencari informasi tentang SMK PGRI 1 Kota Serang lebih mudah mengetahui sekolah tersebut berkerja sama dengan perusahaan apa saja dan ketika di klik langsung menuju halaman website perusahaannya untuk mengetahui lebih jauh profil dari perusahaan. Hasil revisi dari saran yang telah diberikan dapat dilihat pada Gambar 6 .

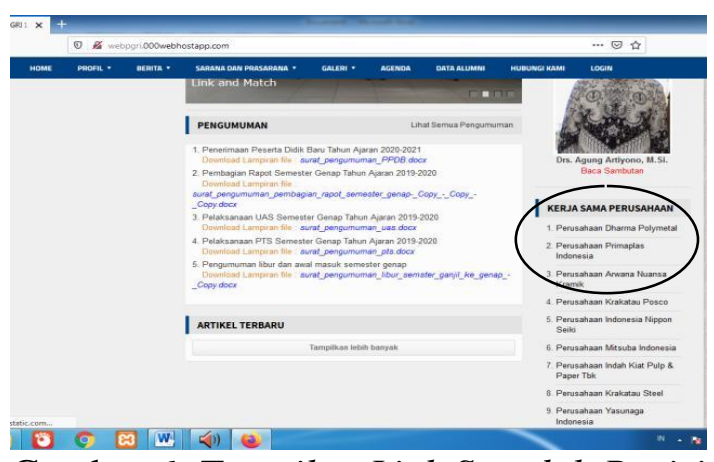

Gambar 6. Tampilan Link Sesudah Revisi

Pada ahli media dua juga memberikan saran agar produk yang dibuat menjadi lebih baik dan relevan lagi. Saran yang diberikan oleh ahli media dua ini diantaranya: memperbaiki tata letak menu-menu pada halaman utama serta memperbaiki kombinasi warna-warna pada website. Setelah mendapat saran dari ahli media dua dengan begitu website sistem informasi sekolah SMK PGRI 1 Kota Serang diubah berdasarkan saran yang telah diberikan (Kuncoro, 2020).

Sebelum dilakukannya perbaikan, menu-menu yang terdapat pada website masih terlihat berantakan dan tidak beraturan. Profil sekolah dan sarana prasarana masih dalam bentuk side bar yang ada di sebelah kiri, bukan dalam bentuk menu.Sehingga saran yang diberikan oleh ahli media dua pada perbaikan ini agar profil sekolah dan sarana prasaran dibuat dalam bentuk menu. Selain itu album foto dan vidio digabung menjadi sebuah menu bernama galeri serta ditambahkan beberapa menu lain dan dihapusnya beberapa menu yang tidak penting dalam website informasi sekolah. Berikut ini tampilan setelah direvisi yang dapat dilihat pada Gambar 7. 


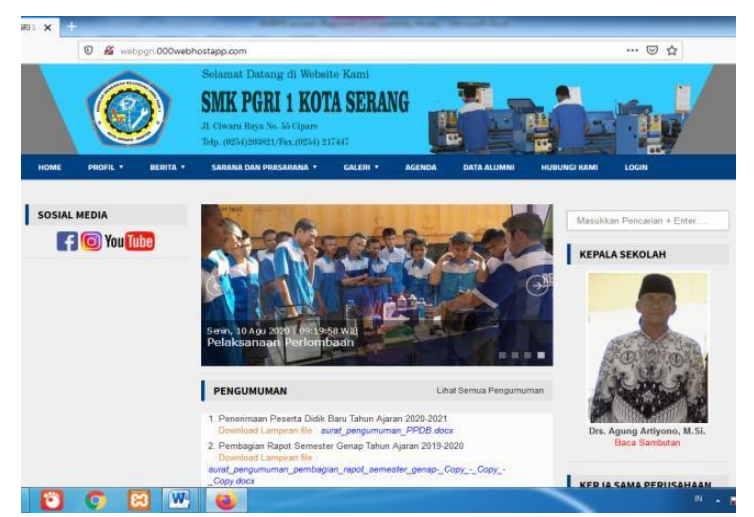

Gambar 7. Tampilan Tata Letak Menu Sesudah Direvisi

Pada tampilan login ini, userakan diminta untuk memasukan username dan password yang sudah diberikan oleh admin untuk bisa masuk ke halaman yang dituju.User siswa akan diminta untuk memasukan username menggunakan NIS masisng-masing siswa dan password nya juga menggunakan NIS masing-masing siswa. Jika terjadi kesalahan pada username atau password nya maka akan terlihat peringatan pada tampilan login tersebut dan meminta untuk memasukan kembali username dan password nya. Gambar 8 merupakan tampilan login pada website yang dapat dilihat di bawah ini.

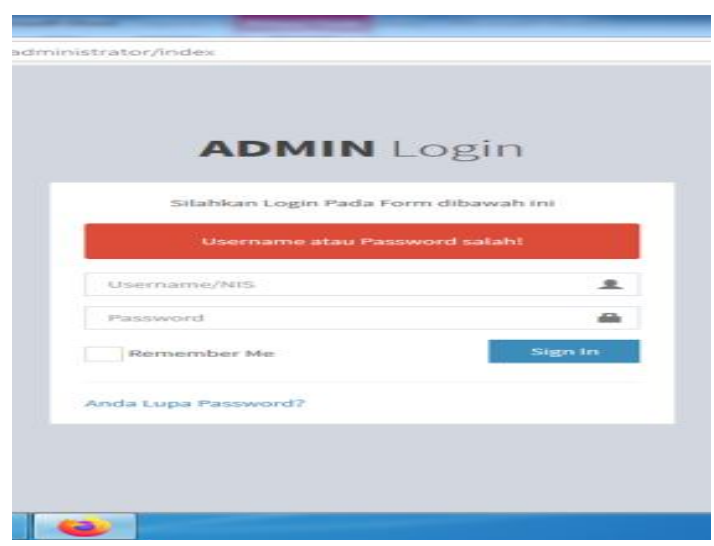

Gambar 8. Tampilan Halaman Login

User dalam website sistem informasi sekolah ini terbagi menjadi dua yaitu user siswa dan admin. Pada user siswa, ketika siswa sudah masuk menggunakan username dan password maka websiteakan masuk ke halaman depan user siswa atau dashboard. Halaman depan siswa ini terbagi beberapa menu yaitu dashboard, data master, transaksi, laporan, edit profil, logout. Pada halaman dashboard maka akan muncul tampilan keterangan username, nama lengkap, nomer telpon serta alamat email yang bisa diubah-ubah pada menu edit profil. Pada menu data master akan disuguhkan informasi detail tentang siswa. Menu transaksi pada halaman siswa berisikan daftar pembayaran siswa dari awal hingga akhir. Selanjutnya menu laporan yang berisikan data laporan tunggakan siswa dan yang terakhir menu edit profil untuk mengedit profil siwa salah satunya password. Tampilan halaman utama user siswa dapat dilihat seperti Gambar 9.

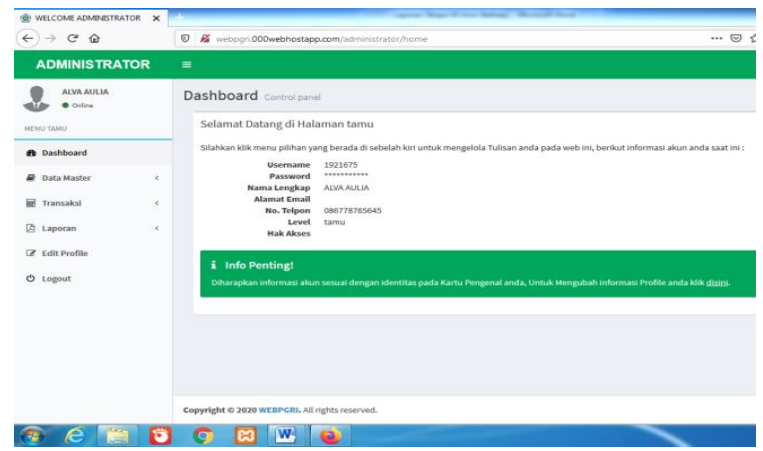

Gambar 9. Tampilan Halaman Siswa

User admin dalam website informasi sekolah ini menjadi inti dalam merubah data-data pada website sistem informasi sekolah. Setelah user admin sudah memasukan username dan password maka akan masuk ke halaman depan user admin atau dashboard. Dalam halaman admin ini terdapat banyak sekali menu-menu diataranya menu data master, transaksi, laporan, menu utama, modul berita, modul vidio, modul iklan, modul web, modul interaksi, modul users, modul sekolah, edit profil dan logout. Pada halaman admin ini juga terdapat grafik kunjungan website untuk melihat seberapa banyak orang-orang yang mengunjungi website 
sekolah ini per bulannya. Tampilan halaman user administrasi seperti Gambar 10.

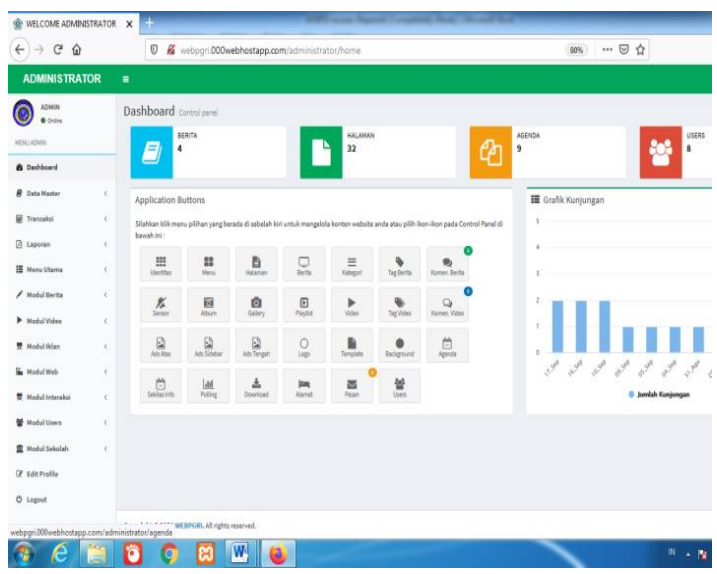

Gambar 10. Tampilan Halaman Utama Admin

Penelitian rancang bangun sistem informasi sekolah berbasis website ini dibuat dengan tujuan untuk melakukan pengembangan sistem informasi sekolah yang masih berbentuk manual kedalam bentuk website sehingga lebih mudah dalam mendapatkan informasi tentang SMK PGRI 1 Kota Serang.Selain itu penelitian ini juga bertujuan untuk mengetahui tingkat kelayakan dari website yang sudah dibuat ini.Pengembangan sistem informasi sekolah berbasis website ini melalui empat tahapan diantaranya tahap analisis, tahap desain, tahap pemrograman, dan tahap pengujian. Pada tahap pertama peneliti melakukan tahapan analisis kebutuhan sebuah sistem informasi yang mana digunakan untuk memudahkan masyarakat, guru, dan murid dalam mendapatkan informasi sekolah. Data analisis kebutuhan ini didapat dari hasil wawancara oleh wakil kepala bidang kurikulum SMK PGRI 1 Kota Serang dan hasil observasi ke sekolah. Pada hasil wawancara dan observasi ke sekolah di dapatkan bahwa sekolah membutuhkan sebuah sistem informasi yang dapat dengan mudah di akses, cepat dan akurat sehingga solusi dari kebutuhan itu dibuatkanlah sistem informasi sekolah dengan berbasis website.

Tahap kedua adalah pembuatan desain sistem informasi sekolah berbasis website.Tahap desain sistem informasi sekolah ini memeiliki tahapan-tahapan diantaranya yaitu penyusunan flowchart untuk user admin dan user siswa, tahap pembuatan storyboard, penetapan konten, penyususnan konten dan terakhir pembuatan layer dan database.Pembuatan flowchart bertujuan untuk mengetahui ketika kita masuk sebagai user admin maka hal yang dapat kita lakukan yaitu menginput data-data sekolah, menginput data pembayaran, dan menambah user.Sedangkan ketika kita masuk sebagai user siswa maka kita dapat melakukan monitoring pembayaran serta melihat data tunggakan yang harus dibayar ke sekolah.Selain itu user siswa juga dapat mengubah password untuk masuk ke halaman utama user siswa itu sendiri. Kemudian pembuatan storyboard yang menggambarkan penempatan letak menu pada tampilan website sehingga lebih terstruktur dan sesuai dengan alur yang sudah direncanakan sebelumnya. Selanjutnya penetapan konten pada website informasi sekolah yang ditentukan berdasarkan kebutuhan dalam penyampaian informasi sekolah tersebut.Penetapan konten ini terdapat dua user yaitu user administrasi dan user siswa.Penetapan konten dibuat terlebih dahulu sebelum dilakukannya penyusunan konten yang dimasukan pada website yang dibuat.

Tahap ketiga adalah proses pembuatan website dengan penulisan program atau coding yang mampu menghasilkan rancangan sistem informasi sekolah berbasis website. Pemrograman atau coding ditulis menggunakan sublime teks, dan didalam program ini peneliti menggunakan bahasa PHP dan javasript. Setelah itu 
bahasa pemrograman di lakukan penyusunan menjadi sebauh program yang utuh dan mengikuti proses alur yang sudah dibuat sebelumnya.Hasil percobaan pada website yang dibuat ini dilakukan oleh dua validator dengan penilaian dan saran yang sudah diberikan. Penilaian keseluruhan yang dicapai mengenai sistem informasi sekolah berbasis website ini mendapatkan skor rara-rata sebesar 72,5 dengan kategori sangat layak. Tetapi tentu masih terdapat beberapa kesalahan yang terjadi pada website setelah itu validator memberikan saran untuk diperbaiki kesalahan tersebut.Penambahan saran yng diberikan oleh validator diantaranya yaitu memperbaiki kalimat yang salah, menambahkan menu-menu yang lebih penting dan menghapus menu-menu yang tidak penting, dan terkahir memperbaiki warna dasar yang sesuai dan menarik.Sehingga pada tahap revisi produk, peneliti pun mengikuti penambahan saran yang diberikan oleh validator agar website informasi sekolah yang dibuat menjadi lebih baik dari sebelumnya.

Tahap ke empat atau terkahir yaitu tahap pengujian.Tahap pengujian ini adalah tahap dimana sudah melewati tahap analisis, tahap desain dan tahap pemrograman secara menyeluruh. Obyek dari pengguna atau ujicoba adalah guru, masyarakat, siswa, dan staff SMK PGRI 1 Kota Serang. Berdasarkan hasil penilaian tolal berdasarkan tiga aspek diantaranya yaitu aspek akurasi, komunikasi visual dan penginputan data menghasilkan jumlah skor rata-rata sebesar 71,96 dengan kategori sangat layak.

Website sistem informasi sekolah dinilai kelayakannya oleh ahli media dan ujicoba pengguna. Ahli media akan memberi penilaian melihat dari dua aspek yaitu aspek dari tampilan dan komunikasi visual. Untuk ujicoba pengguna akan memberi penilaian melihat dari tiga aspek yaitu aspek akurasi, aspek komunikasi visual dan aspek penginputan data. Selain penilaian dari beberapa aspek diatas ahli media juga memeberi saran untuk perbaikan produk sistem informasi sekolah berbasis website ini. Berikut ini penilaian yang diberikan oleh ahli media terdapat pada Gambar 11 yaitu aspek tampilan dan Gambar 12 yaitu aspek komunikasi visual di bawah ini:

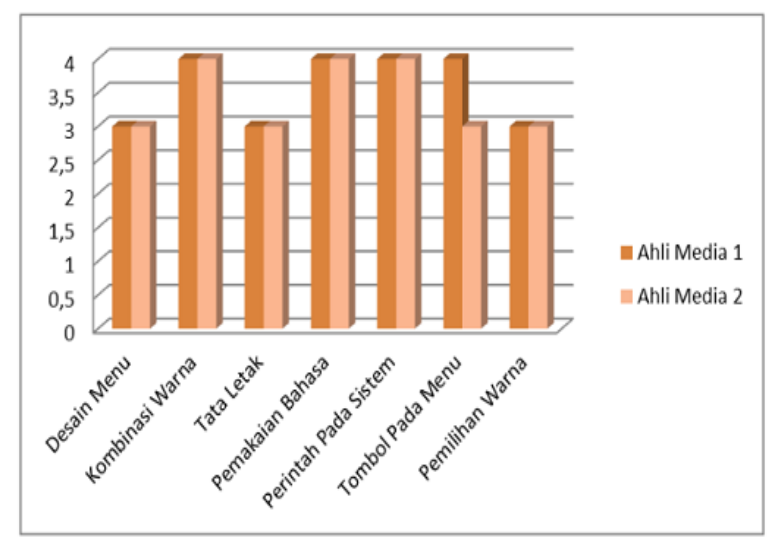

Gambar 11. Aspek Tampilan Ahli Media

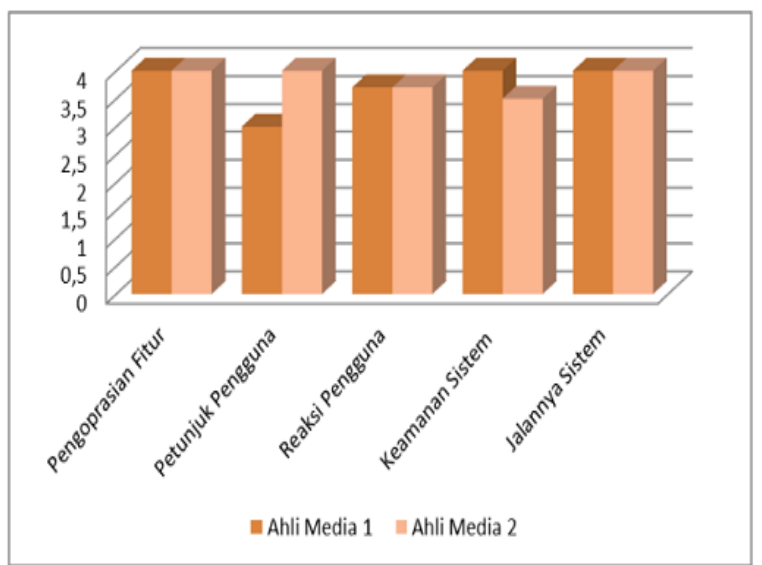

Gambar 12. Aspek Komunikasi Visual Ahli Media

Berdasarkan penilaian dari ahli media bahwa sistem informasi sekolah berbasis website sudah cukup baik dari segi tampilan, penyusunan menu dan penempatan item di setiap konten yang telah berfungsi dengan baik dan mudah digunakan.Jumlah skor aspek tampilan 
dari penilaian yang didapat sebesar 30 dari ahli media satu dan sebesar 31 dari ahli media dua dengan jumlah skor maksimal 36.Sedangkan dalam aspek komunikasi visual dengan penilaian pengoprasian fitur, petunjuk pengguna, reaksi pengguna, keamanan sistem, dan jalannya sistem pada ahli media satu dan ahli media dua memberi jumlah skor sebesar 42 dengan skor maksimal 44. Berdasarkan dari jumlah total rata-rata ahli media mendapat skor total sebesar 72,5 dengan kategori sangat layak.

\section{Tanggapan Pengguna Website Sistem Informasi Sekolah}

Penilaian yang dilakukan kepada penggua yaitu dengan melakukan ujicoba di lapangan.Respon dari tujuan ini adalah untuk mengetahui tanggapan dari website sistem informasi sekolah yang meliputi tiga aspek yaitu aspek akurasi, komunikasi visual, dan penginputan data.Selain itu pengguna juga boleh memberi saran agar website sistem informasi sekolah bisa menjadi lebih baik.Tanggapan dari ujicoba penggunadapat dilihat pada Gambar 13.

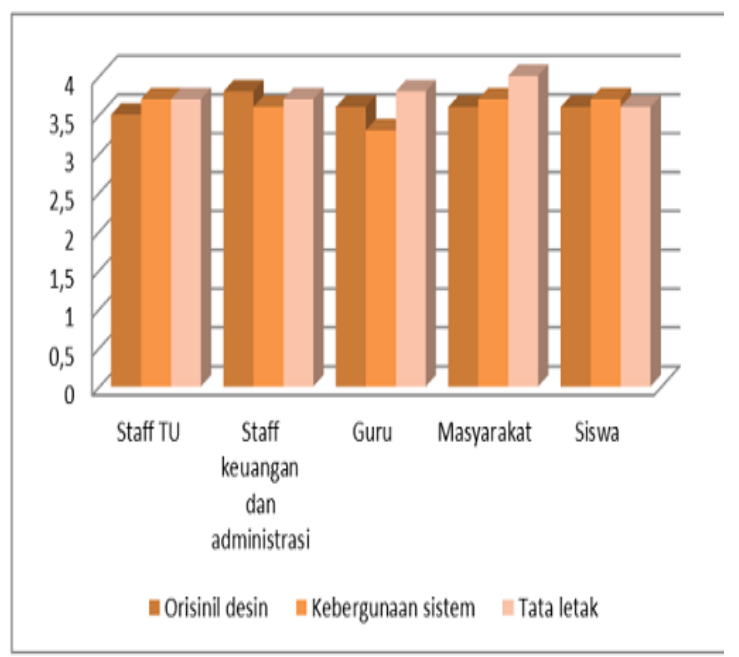

Gambar 13. Aspek Akurasi Pengguna

Berdasarkan diagram batang diatas terdapat beberapa hasil respon yang sudah didapatkan dari pengguna.
Pengguna dari website ini terdapat beberapa kategori yaitu staff TU, staff keuangan dan administrasi, guru, masyarakat dan siswa. Pada aspek akurasi terdapat tiga penilaian yaitu orisinil desain, kebergunaan sistem atau website, dan tata letak. Hasil rata-rata yang telah didapat dari penilaian orisinil desain yaitu staff TU sebesar 3,5 staff keuangan dan administrasi sebesar 3,8 guru, masyarakat dan siswa sebesar 3,6 dengan skor maksimal 4. Pada penilaian kebergunaan sistem atau website yaitu staff TU, masyarakat dan siswa mendapat nilai rata-rata sebesar 3,7 staff keuangan dan administrasi sebesar 3,6 dan guru sebesar 3,3 dari skor maksimal 4. Pada penilaian tata letak hasil skor rata-rata yang didapat yaitu staff TU dan staff keuangan administrasi mendapat skor 3,7 guru sebesar 3,8 masyarakat 4 dan siswa 3,6 dengan skor maksimal 4. Berikut aspek komunikasi visual dari pengguna dapat dilihat dari Gambar 14.

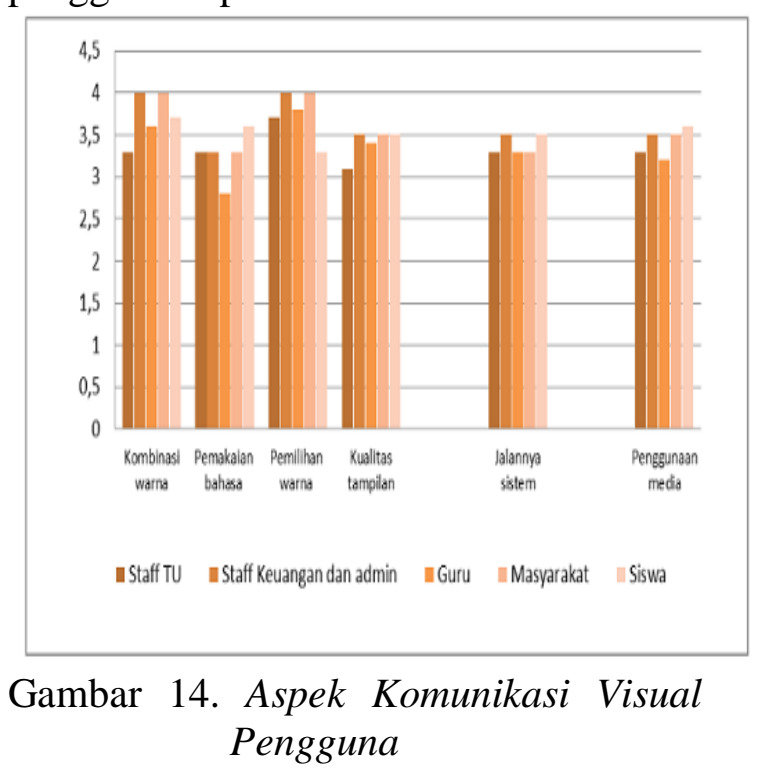

Berdasarkan diagram batang diatas telah didapatkan hasi penilaian dari pengguna. Pada aspek komunikasi visual terdapat beberapa penilaian yaitu kombinasi warna, pemakaian bahasa, pemilihan warna, kualitas tampilan, jalannya sistem dan penggunaan media. 
Hasil rata-rata yang telah didapat dari kombinasi warna yaitu staff TU sebesar 3,3 staff keuangan dan administrasi serta siswa sebesar 4 guru sebesar 3,6 dan siswa sebesar 3,7 dengan skor maksimal 4. Pada penilaian pemakaian bahasa hasil rata-rata yang telah didapat yaitu staff TU, staff keuangan dan administrasi serta masyarakat sebesar 3,3 guru sebesar 2,6 dan siswa sebesar 3,6 dengan skor maksimal 4.

Penilaian pemilihan warna hasil rata-rata yang didapat yaitu staff $\mathrm{TU}$ sebesar 3,7 staff keuangan dan administrasi serta masyarakat sebesar 4 sedangkan guru dan siswa sebesar 3,8 dan 3,4 dengan skor maksimal 4. Pada penilaian kualitas tampilan pada staff TU sebesar 3,1 staff keuangan dan administrasi, masyarakat dan siswa sebesar 3,5 dan guru sebsar 3,4 dengan skor maksimal 4.

Jalannya sistem didapatkan nilai staff TU dan guru mendapat skor sebesr 3,3 dan masyarakat, siswa dan staff keuangan dan administrasi sebesar 3,5 dengan skor maksimal masih sama yaitu 4. Terakhir yaitu penilaian penggunaan media dengan staff TU sebesar 3,3 staff keuangan dan administrasi serta masyarakat sebesar 3,5 guru 3,2 dan terakhir siswa sebesar 3,6 dengan skor maksimal 4. Aspek berikutnya yaitu aspek penginputan data yang terdapat seperti Gambar 15 di bawah ini.

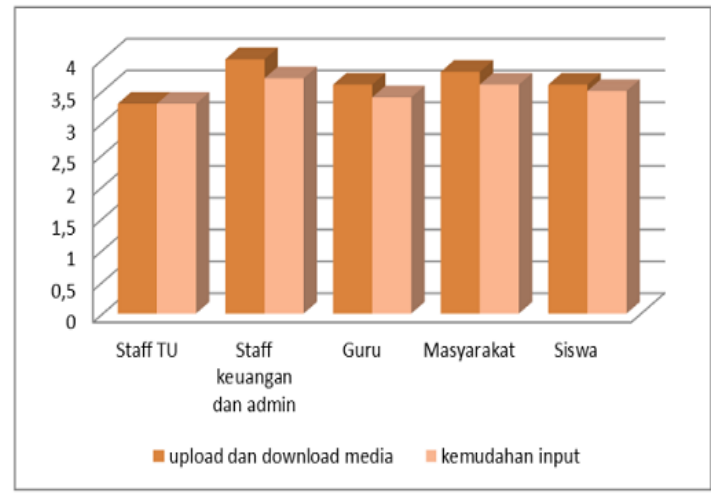

Gambar 15. Aspek Penginputan Data Pengguna
Aspek terakhir yaitu aspek penginputan data. Pada aspek ini terdapat dua penilaian yaitu upload dan download media serta kemudahan input. Hasil skor rata-rata yang didapat dari penilaian upload dan download media adalah staff TU sebesar 3,3 staff keuangan dan administrasi sebesar 4 guru dan siswa sebesar 3,6 dan masyarakat sebesar 3,8 dengan skor maksimal 4. Sedangkan penilaian kemudahan input didapat hasil skor rata-rata yaitu staff TU 3,3 staff keuangan dan administrasi 3,7 guru sebesar 3,4 masyarakat 3,6 dan siswa 3,5 dengan skor maksimal 4.

\section{KESIMPULAN}

Berdasarkan hasil penelitian sistem informasi sekolah berbasis di SMK PGRI 1 Kota Serang dapat disimpulkan sebagai berikut.

1. Sistem informasi sekolah berbasis website dikembangkan menggunakan metode R\&D. Dengan model waterfall dengan tahapan-tahapan penelitian diantaranya yaitu analisis, desain, pemrograman dan pengujian. Proses pembuatan sistem informasi sekolah berbasis website ini diantaranya yaitu membuat flowchart dan storyboard, menetapkan dan menyusun konten, merancang proses alur sistem informasi sekolah berdasarkan dengan susunan konten yang sudah dibuat, melakukan perancangan database menggunakan webserver XAMPP, selanjutnya menuliskan code menggunakan bahasa program PHP untuk memproses data pada website dengan bantuan aplikasi sublime text editor. Selanjutnya setelah sudah melakukan pemrograman kemudia website yang sudah di buat tersebut di hoasting agar bisa terhubung secara online.

2. Tingkat kelayakan pada sistem informasi sekolah berbasis website ini dinilai dari ahli media dan pengguna 
yaitu staff TU, staff keuangan dan administrasi, guru, siswa dan masyarakat. Penilaian oleh ahli media mendapatkan skor rata-rata 72,5 yang berdasarkan tabel konfigurasi kelayakan menyatakan sangat layak, skor rata-rata dari pengguna sebesar 71,96 yang berdasarkan tabel konfigurasi kelayakan menyatakan sangat layak

Sistem informasi sekolah berbasis website dalam pemanfaatannya yaitu dapat membantu penyampaian informasi sekolah secara luas dengan bantuan internet cepat dan mudah sehingga peneliti memberi saran sebagai berikut: (1) pada saat ingin membuka website sistem informasi SMK PGRI 1 Kota Serang pastikan terlebih dahulu komputer sudah terhubung dengan jaringan internet. (2) diperlukan pengecekan secara rutin maupun berkala sistem informasi sekolah berbasis website ini berjalan dengan baik dan sesuai atau tidak, dan (3) pada peneliti selanjutnya sebaiknya agar dapat membuat konten-konten yang dapat lebih bermanfaat untuk SMK PGRI 1 Kota Serang kedepannya.

\section{DAFTAR PUSTAKA}

Adetokunbo, \& Basirat. (2013). Software Engineering Methodologies: A Review of theWaterfall Model and Object-Oriented Approach. International Journal of Scientific \& Engineering Research, Vol.4, No.7, hal 427-434.

Anggraini, S., Sofiyan, A., \& Khumaini, H. (2018). Sistem Informasi Pembayaran SPP di SMK Negeri 4 Dumai Bebasis SMS Gateway. Jurnal Informatika, Manajemen dan Komputer, Vol.10, No.2, hal 66-72.

Anita, S., \& Tasrif, E. (2019). Pengaruh Internet dan Motivasi Terhadap Hasil Penyelesaian Tugas Pelajaran
Dasar Desai Grafis. Voteknika, Vol.7, No.1, hal 100-105.

Baihaqi, M. (2019). Pengembangan Sistem Informasi Prakerin Berbasis Android di Jurusan Elektronika Industri SMK Negeri 1 Cikande. Skripsi, FKIP, Pendidikan Vokasional Teknik Elektro, Universitas Sultan Ageng Tirtayasa, Serang.

Das, R., \& Saikia, L. (2016). Comparison of Procedural PHP with Codeigniter Framework. International Journal of Advanced Research in Computer Science and Software Engineering, Vol.6, No.2, hal 339-342.

Destiningrum, M., \& Adrian, Q. (2017).

Sistem Informasi Penjadwalan

Dokter Berbasis Web Dengan Menggunakan Framework Codeigniter. Teknoinfo, Vol.11, No.2, hal 30-37.

Fahmi, S., \& Priwantoro, S. (2017). Pengembangan Media Belajar Untuk Mata Kuliah Logika Matematika dan Himpunan di Program Studi Pendidikan Matematika Universitas Ahmad Dahlan. AdMathEdu, vol.7, No.2, hal 177-196.

Fauzi, A., Erniawati, \& Setyawan, A. (2019). Sistem Informasi Pemesanan Kertas Continous Form PT. Erajaya Mandiri Pratama Jakarta. Teknologi Informasi \& Komputer, Vol.5, No.1, hal 123127.

Hanapi, Y. (2019). Perjanjian Terhadap Kontrak Perdagangan Melalui Internet. Surya Keadilan, Vol.3, No.1, hal 1-20.

Hariyanto, D., \& Prasetyo, F. (2019). Penerapan Metode Unified Approach Pada Sistem Informasi Akademik Berbasis Website . Khatulistiwa Informatika, Vol.7, No.1, hal 21-28. 
Hastanti, R., Purnama, B., \& Wardati, E. (2015). Sistem Penjualan Berbasis Web (E-Commerce) Pada Tata Distro Kabupaten Pacitan. Bianglala Informatika, Vol.3, No.2, hal 1-9.

Herdiansyah, H. (2013). Wawancara, Observasi dan Focus Groups. Jakarta: Raja Grafindo Persada.

Hidayat, A., \& Faisal. (2019). Rancang Bangun Sistem Informasi Penyewaan Lahan Parkir Berbasis Web GIS. Sistem Informasi dan Sains Teknologi, Vol1., No.1, hal 1-9.

Hustinawati, Himawan, A., \& Latifah. (2014). Performance Analysis Framework Codeigniter and CakePHP in Website Creation. International jurnal of computer aplication, Vol.94, No.20, hal 611.

Kuncoro, B. A. (2020). Rancang Bangun Sisem Informasi Sekolah (SIS) Berbasis Website di SMK PGRI 1 Kota Serang.Skripsi.Universitas Sultan Ageng Tirtayasa. Serang: Banten.

Kuswanto, H. (2017). Analisis Prinsip Layout and Composition pada Web Design Perusahaan PT. Bank Rakyat Indonesia, Tbk dan PT. FIF Group berdasarkan Buku "The Principle of Beautifull Website Design (2nd Edition) By Jason Beaird". ELINVO, Vol.2, No.1, hal:1-7.

Manurung, I. (2019). Sistem Informasi Lembaga Kursus dan Pelatihan (LKP) City Com Berbasis Web Menggunakan PHP dan MySQL. Mahajana Informasi, Vol.4, No.1, hal 42-50.

Meilani. (2013). Teori Warna: Penerapan Lingkaran Warna dalam Berbusana. Humaniora, Vol.04, No.1, hal:326-338.
Monica. (2016). Pengaruh Warna, Tipografi, dan Layout Pada Desain Situs . Humaniora, Vol.01, No.2, hal:459-468.

Mubarak, A. (2019). Rancang Bangun Aplikasi Web Sekolah Menggunakan UML (Unified Modeling Language) dan Bahasa Pemrograman PHP (PHP Hypertext Preprocessor) Berorientasi Objek. JIKO, Vol.2, No.1, hal 19-25.

Nasution. (2016). Metode Research. Jakarta: Bumi Aksara.

Nugroho, A. (2015). Rekayasa Perangkat Lunak Menggunakan UML dan Java. Yogyakarta: ANDI.

Pamungkas, C. (2015). Pemanfaatan Codeigniter Framework dalam Membangun SMS Gateway Berbasis Gammu. Informa, Vol.1, No.1, hal 1-10.

Prabowo, D. (2015). Website ECommerce Menggunakan Model View Controller Dengan Framework Codeigniter. DASI, Vol.16, No. 1, hal 23-29.

Pressman, R. (2019). Rekayasa Perangkat Lunak: Pendekatan Praktis. Yogyakarta: ANDI.

Putra, S., \& Sutjahjo, G. (2017). Sistem Informasi Diklat Pegawai Pada BP Batam Berbasis Smartphone Android Dengan Ionic Framework dan Database MySQL. Zona Komputer, Vol.7, No.3, hal 47-64.

Rahman, B., Susetyo, B., \& Primasari , D. (2019). Analisis Kinerja Pelayanan Surat-Menyurat Berbasis Web di PGRI Kabupaten Bogor. IKRA-ITH Informatika, Vol.3, No.1, hal 1-12.

Rosa, \& Shalahuddin, M. (2018). Rekayasa Perangkat Lunak Terstruktur dan Berorientasi Objek. Bandung: Informatika . 
Sihombing, J., \& Khumaini, H. (2016). Sistem Informasi Penjualan Game PC Berbasis Web Pada Toko OE Game Menggunakan PHP. Informatika,Manajeman \& Komputer, Vol.8, No.2, hal 43-48.

Siregar, M., \& Saiman, S. (2019). Pengembangan Web Perpustakaan Pada Sekolah Menengah Kejuruan Negeri 4 Kendari. Router Search, Vol1, No.1, hal 8-15.

Solanki, N., Shah, D., \& shah, A. (2017). A Survey on different Framework of PHP. International Journal of Latest Technology in Engineering, Management \& Applied Science (IJLTEMAS), Vo.6, No.6, hal 155158.

Solikhin, A., \& Riasti, B. (2013). Pembangunan Sistem Informasi Inventarisasi Sekolah Pada Dinas Pendidikan kabupaten Rembang Berbasis Web . IJNS, Vol.2, No.2, hal 50-57.

Sugiyono. (2014). Metode Penelitian Kuantitatif, Kualitatif dan $R \& D$. Bandung: Alfabeta.

Suhartono. (2015). Desain Sistem Mobile Web Store Menggunakan Codeigniter, MySQL dan JQUERY Mobile. Dinamika, Vol.6, No.2, hal 43-49.

Suryadi , A., \& Zulaikhah, Y. (2019). Rancang Bangun Sistem Pengelolaan Arsip Surat Berbasis Web Menggunakan Metode Waterfall. Khatulistiwa Informatika, Vol.7, No.1, hal 1321.

Syam, A., \& Arie, J. (2018). Aplikasi Rekam Medis Berbasis Web. Sistenm Informasi dan Teknologi Informasi, Vol.7, No.1, hal 1-9.

Talika, F. (2016). Manfaat Internet Sebagai Media Komunikasi Bagi Remaja di Desa Air Mangga Kecamatan Laiui Kabupaten
Halmahera Selatan. Acta Diurna, Vol.5, No.1, hal 1-6.

Wardani, S. (2013). Sistem Informasi Pengolahan Data Nilai Siswa Berbasis Web Pada Sekolah Menengah Atas (SMA) Muhammadiyah Pacitan. IJNS, Vol.2, No.2, hal 30-37.

Zohrani, \& Aniah, B. (2017). Pengembangan Bahan Ajar IPS Berbasis Teori Belajar Jerome S. Bruner Kelas V Madrasah Ibtidaiyah Unwanul Falah NW Paok Lombok . DIDIKA, Vol.1, No.2, hal 68-80. 